\title{
COVID-19 preparedness: capacity to manufacture vaccines, therapeutics and diagnostics in sub-Saharan Africa
}

\author{
Bisi Bright ${ }^{1,2}$, Chinedum Peace Babalola 1,3,4,5,6, Nadia Adjoa Sam-Agudu1,7,8,9, \\ Augustine Anayochukwu Onyeaghala,10,11, Adebola Olatunji 1,12, Ufuoma Aduh 1,13, Patrick O. Sobande ${ }^{1,14}$, \\ Trevor A. Crowell ${ }^{15,16}$, Yenew Kebede Tebeje ${ }^{17}$, Sunny Phillip ${ }^{1,7}$, Nicaise Ndembi ${ }^{1,7,8,17,18}$ and \\ Morenike Oluwatoyin Folayan ${ }^{1,19^{*}}$ (D)
}

\begin{abstract}
Objective: The COVID-19 pandemic is a biosecurity threat, and many resource-rich countries are stockpiling and/or making plans to secure supplies of vaccine, therapeutics, and diagnostics for their citizens. We review the products that are being investigated for the prevention, diagnosis, and treatment of COVID-19; discuss the challenges that countries in sub-Saharan Africa may face with access to COVID-19 vaccine, therapeutics, and diagnostics due to the limited capacity to manufacture them in Africa; and make recommendations on actions to mitigate these challenges and ensure health security in sub-Saharan Africa during this unprecedented pandemic and future publichealth crises.

Main body: Sub-Saharan Africa will not be self-reliant for COVID-19 vaccines when they are developed. It can, however, take advantage of existing initiatives aimed at supporting COVID-19 vaccine access to resource-limited settings such as partnership with AstraZeneca, the Coalition for Epidemic Preparedness and Innovation, the Global Alliance for Vaccine and Immunisation, the Serum Institute of India, and the World Health Organization's COVID-19 Technology Access Pool. Accessing effective COVID-19 therapeutics will also be a major challenge for countries in sub-Saharan Africa, as production of therapeutics is frequently geared towards profitable Western markets and is illadapted to sub-Saharan Africa realities. The region can benefit from pooled procurement of COVID-19 therapy by the Africa Centres for Disease Control and Prevention in partnership with the African Union. If the use of convalescent plasma for the treatment of patients who are severely ill is found to be effective, access to the product will be minimally challenging since the region has a pool of recovered patients and human resources that can man supportive laboratories. The region also needs to drive the local development of rapid-test kits and other diagnostics for COVID-19.

(Continued on next page)
\end{abstract}

\footnotetext{
* Correspondence: toyinukpong@yahoo.co.uk

${ }^{1}$ COVID-19 Think Tank, Nigeria

${ }^{19}$ Department of Child Dental Health, Obafemi Awolowo University, Ile-Ife, Nigeria

Full list of author information is available at the end of the article
}

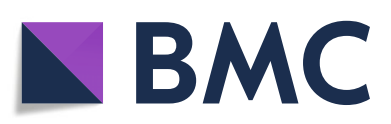

(c) The Author(s). 2021 Open Access This article is licensed under a Creative Commons Attribution 4.0 International License, which permits use, sharing, adaptation, distribution and reproduction in any medium or format, as long as you give appropriate credit to the original author(s) and the source, provide a link to the Creative Commons licence, and indicate if changes were made. The images or other third party material in this article are included in the article's Creative Commons licence, unless indicated otherwise in a credit line to the material. If material is not included in the article's Creative Commons licence and your intended use is not permitted by statutory regulation or exceeds the permitted use, you will need to obtain permission directly from the copyright holder. To view a copy of this licence, visit http://creativecommons.org/licenses/by/4.0/. The Creative Commons Public Domain Dedication waiver (http://creativecommons.org/publicdomain/zero/1.0/) applies to the data made available in this article, unless otherwise stated in a credit line to the data. 


\begin{abstract}
(Continued from previous page)
Conclusion: Access to vaccines, therapeutics, and diagnostics for COVID-19 will be a challenge for sub-Saharan Africans. This challenge should be confronted by collaborating with vaccine developers; pooled procurement of COVID-19 therapeutics; and local development of testing and diagnostic materials. The COVID-19 pandemic should be a wake-up call for sub-Saharan Africa to build vaccines, therapeutics, and diagnostics manufacturing capacity as one of the resources needed to address public-health crises.
\end{abstract}

Keywords: COVID-19, Vaccine, Therapeutics, Diagnostics, Manufacturing capability, Sub-Saharan Africa

\section{Background}

Coronavirus disease 2019 (COVID-19) is a viral infection caused by severe acute respiratory syndrome coronavirus 2 (SARS-CoV-2). By the end of November 2020,, there were over 62 million cases of COVID-19 and 1.4 million deaths (case fatality rate $2.4 \%$ ) had been reported globally [1]. At this time also, Africa had recorded over 2 million COVID-19 cases and over 49,000 [1]. Resource limitations in sub-Saharan Africa contribute to relatively lower access to COVID-19 diagnostic testing, which result in underdiagnosis, especially of asymptomatic or pauci-symptomatic persons, and limited basic and advanced care to prevent morbidity and mortality [2-5]. Notwithstanding, COVID-19 has overwhelmed even highly developed healthcare systems in Europe and the Americas [6-9].

In sub-Saharan Africa, proactive public-health interventions and thoughtful allocation of resources will be needed to prevent poor patient outcomes and control the pandemic. The most widely adopted control measures for COVID-19 are behaviour change and physical/ social distancing, such as closures of schools and/or workplaces, reduction of public and religious gatherings, hand hygiene, respiratory hygiene, proper use of face masks in public places, internal travel restrictions, and border closures $[5,10]$. Guidelines typically require persons diagnosed with COVID-19 to be isolated for a minimum of 10 days (this may be extended for as long as there is no evidence of viral clearance), and 14-day quarantine of their contacts, either in their homes or in dedicated facilities [11]. If appropriately implemented, these measures can reduce disease transmission and slow the spread of SARS-CoV-2 between and within countries. However, eradication of COVID-19 will likely require a safe and effective vaccine to prevent disease acquisition independent of individual behaviours [12]. As of 5th November 2020, there were 104 active studies of candidate COVID-19 vaccines worldwide, registered in Clinicaltrials.gov [13]. Thirteen (12.5\%) of these studies are being conducted in Africa, with 11 (10.6\%) in subSaharan Africa (Table 1). Candidate vaccines in the United Kingdom [14], the United States [15] and China [16] have demonstrated safety and immunogenicity in
Phase I studies, thus providing early and reassuring signals that an effective COVID-19 vaccine is in progress.

Unfortunately, vaccine research and development are lengthy processes that typically require years to complete. Pharmacologic agents that have demonstrated safety for other diseases may be a useful bridge for preventing or treating COVID-19 while an effective vaccine is being developed. Hydroxychloroquine showed promise for pre-exposure prophylaxis against COVID-19 from an observational study pre-print among healthcare workers [17], however it was reported ineffective for postexposure prophylaxis in this population in another study [18]. There are also published COVID-19 protocols of trials of hydroxychloroquine or chloroquine and melatonin as pre-exposure prophylaxis for healthcare workers in Spain [19], but no trials for post- and pre-exposure prophylaxis in sub-Saharan Africa have been as yet registered (Table 1).

For most of the pandemic so far, COVID-19 therapy has focused on symptom control and supportive care. Remdesivir was approved for compassionate use by the United States Food and Drug Administration after a clinical trial showed shorter duration of hospitalization [20] and improved clinical outcomes in hospitalized patients who received the drug [21]. However, other studies, including from China [22] have found only marginal benefits. Recently, preliminary preprint results of the worldwide WHO Solidarity trial among 11,266 adults at 405 hospitals in 30 countries indicated that remdesivir had no measurable benefit in mortality or disease course [23]. Compassionate use of humanized Virus Suppressing Factor-variant 13 (hzVSF-v13) in two Korean patients with severe COVID-19 has also shown promising results [23]. Finally, in a large randomized trial, dexamethasone was found to reduce the risk of death from 41 to $28 \%$ inpatients on mechanical ventilators, and reduced the risk of death among patients receiving oxygen from 25 to 20\% [24]. As of 5th November 2020, there were $22 \mathrm{drug} /$ therapeutics trials being conducted in 11 countries across sub-Saharan Africa (Table 1).

In anticipation of favourable outcomes, plans are being put in place for mass production of effective vaccines and therapeutics. The COVID-19 Therapeutics Accelerator, funded by Bill and Melinda Gates; the Wellcome 


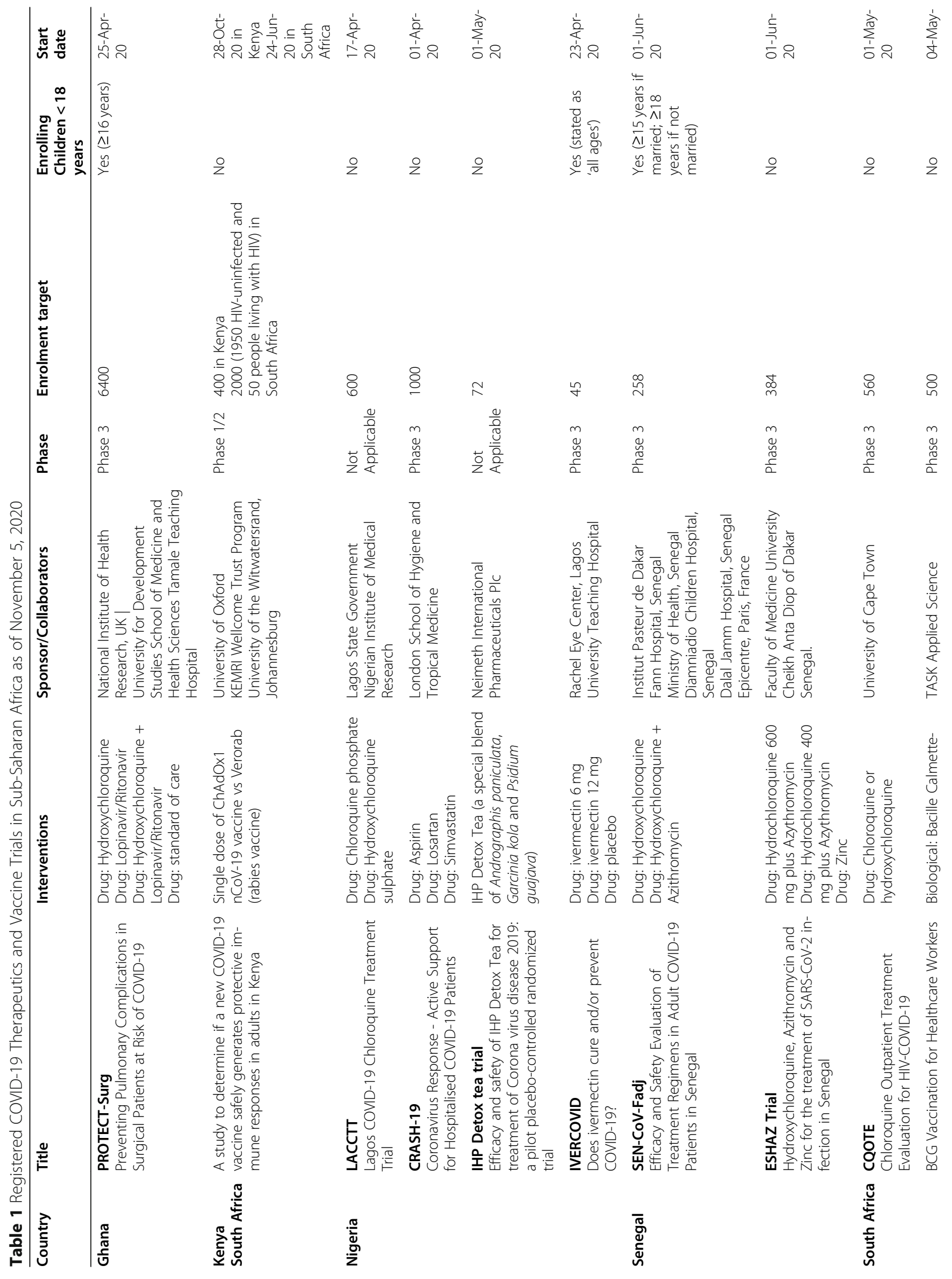




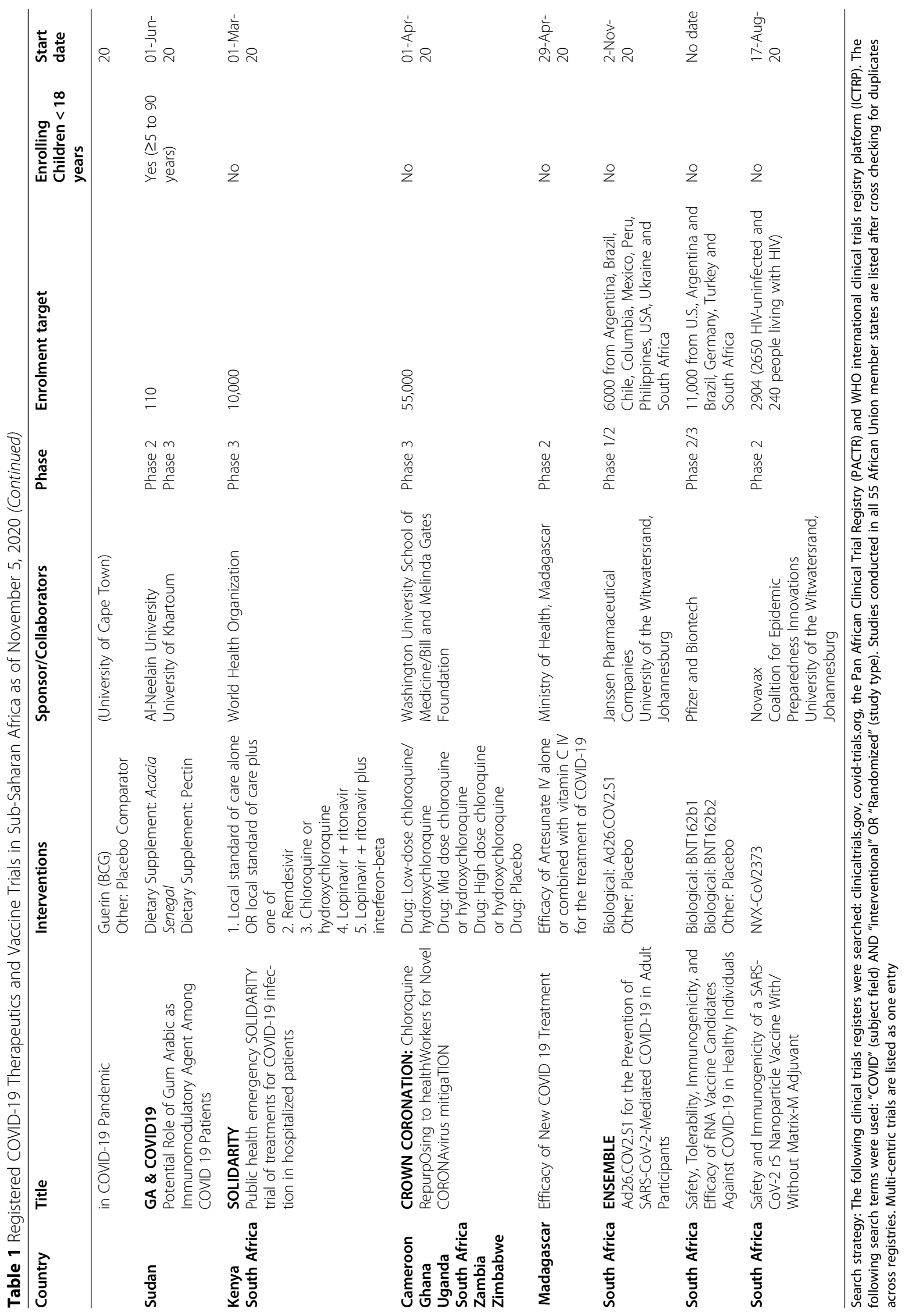


Trust; and the Mastercard Impact Fund plan to work with regulators to fast-track drug approval processes and rapidly manufacture and distribute effective interventions to patients [25]. Mass production of standardized serological assays to detect functional antibodies in different stages and severity of disease, including indicating the presence of protective antibodies will also be needed [26].

In this article, we review products under investigation for the prevention, diagnosis, and treatment of COVID19. We discuss the challenges that countries in subSaharan Africa may face with access to COVID-19 vaccines, therapeutics, and diagnostics due to the limited manufacturing capacity on the continent. Lastly, we make recommendations on actions to mitigate these challenges and ensure health security in sub-Saharan Africa during this unprecedented pandemic. The discussion will also be important for preparedness for COVID19 as well as for future public-health crises.

\section{Vaccines to prevent SARS-CoV-2 infection and COVID-19}

Several COVID-19 vaccine concepts are being tested worldwide, but only five candidate vaccines are being tested in sub-Saharan Africa (Table 1). These include Bacille Calmette-Guérin (BCG) vaccine, historically used for prevention of tuberculosis, and is being evaluated for the prevention of COVID-19 among healthcare workers in South Africa [25]; similar studies are being conducted in Australia, Netherlands, the United States, France and Germany [27-30]. Testing of BCG is felt justified based on its effectiveness in reducing deaths from tuberculosis pneumonia and sepsis-related deaths in neonates, and in reducing respiratory tract infections in adolescents [31, 32]. The mechanism of action against SARS-CoV-2 is not known, but it is theorized that the BCG vaccine might reduce viraemia after SARS-COV-2 exposure, thereby reducing the risk of severe COVID-19 and rapid recovery [30]. Others however counter-hypothesize that provocative epidemiological associations between BCG and better COVID-19 outcomes are a correlation and not causation, in that countries with high coverage for mandatory vaccinations have strong public health systems that are robustly responding to the COVID-19 pandemic [33]. Furthermore people in countries with have high uptake for these mandatory vaccinations are likely to be more risk averse and comply with pandemic control measures [33].

There is also the ChAdOx1 $\mathrm{nCoV}-19$ vaccine trial in South Africa that is recruiting adults with and without HIV infection [34]. This study is conducted in collaboration with the Oxford University and the Jenner Institute, and the same study is also planned for implementation in Kenya [35]. NVX-CoV2373 is a vaccine product of Novavax, a US drug developer of next- generation vaccines for serious infectious diseases, and is being tested in South Africa, in addition to the Ad26.COV2-S, a Johnson \& Johnson product [36]. There are also plans for COVID-19 vaccine trials underway in Uganda in collaboration with the Imperial College London [36].

Although only five discrete vaccine trials are ongoing/ planned for implementation in several countries, subSaharan Africa has the human and institutional resources required to host and participate in many more COVID-19 trials, based on current and past experiences with HIV, Ebola, malaria, and tuberculosis vaccine trials [37-43]. The region also has human-vaccine production plants in Senegal (prequalified yellow fever vaccine) and South Africa (fill-finish) [44, 45]. Although no country in sub-Saharan Africa produces BCG vaccines, those countries with fill-finish vaccine may be able to negotiate with vaccine manufacturers to produce COVID-19 vaccines to meet the region's need, if said vaccines are found effective..

\section{Pharmacologic interventions to prevent and treat COVID- 19}

Medications for pre- and post-exposure prophylaxis against other infectious diseases such as HIV, have been proven to curb the spread of infections in key populations. Also, the prompt identification and treatment of patients with COVID-19 will decrease morbidity, mortality, and transmission of the SARS-CoV-2 virus. Several products, re-purposed after being investigated or licensed for use in other infectious diseases, are being investigated for potential roles in prophylaxis and therapy for COVID-19. These products act by five mechanisms: inhibition of virus replication, inhibition of entry of the virus into cells, killing the virus, augmenting a physiologic immune response, or treating symptoms. The drugs can be classified into antivirals, anti-parasitics, antibiotics, and immunomodulators.

\section{Antivirals}

Major antivirals that have in vitro activity against SARS$\mathrm{CoV}-2$, have undergone or are undergoing investigation, and/or are approved for compassionate use are: lopinavir/ritonavir [46], favipiravir [47], umifenovir [48], and remdesivir [21, 46, 49]. Lopinavir/ritonavir is a boosted protease inhibitor widely used for treatment of HIV in low- and middle-income countries and especially in subSaharan Africa. Early evidence suggested that lopinavir/ ritonavir has little to no effect in the treatment of COVID-19 [50, 51], and the World Health Organisation Solidarity trial also found no effect of lopinavir alone and with interferon-beta 1a [23]. However, recent studies report provocative findings regarding possible benefits of lopinavir/ritonavir in combination with ribavirin 
and interferon-beta $1 \mathrm{~b}$ in mild to moderate disease [52]. Favipiravir is an RNA polymerase inhibitor used for the treatment of novel strains of influenza in Japan [53].. Umifenovir (also known as arbidol) is a viral fusion inhibitor used for treatment of influenza in Russia and China, and in a recent Chinese study (in preprint), patients had inferior clinical recovery rate and relief from COVID-19-related fever and cough compared to favipiravir [54].

To date, remdesivir, an RNA viral polymerase inhibitor, has been the most promising antiviral against COVID-19. In a large randomized trial, it shortened length of hospitalization and improved clinical outcomes among patients who required mechanical ventilation [21]. Remdesivir is manufactured in the United States and has been approved for compassionate use for treatment of severe COVID-19 in that country, and in Japan, Singapore, and India [55-58]. The drug is given by intravenous infusion for five to 10 days, and costs approximately $£ 2000$ [€2205; \$2600] per course [59], although the manufacturer Gilead has announced that the cost of a five day course will likely drop [60]. The global WHO Solidarity trial however showed no impact or trend for remdesivir towards improving 28-day mortality among COVID-19 patients [23, 59].

\section{Antiparasitics}

The main anti-parasitics of interest for COVID-19 prevention and treatment are chloroquine and hydroxychloroquine, which have been used as anti-malarial drugs in low- and middle-income countries for nearly 80 years. While both antiparasitics have in vitro activity against SARS-CoV-2, hydroxychloroquine is a more potent [61] and less toxic derivative of chloroquine [62]. Metanalyses and large trials evaluating chloroquine and/ or hydroxychloroquine for COVID-19 treatment (including the WHO Solidarity trial) have showed no efficacy in reducing mortality, need for mechanical ventilation, or duration of hospital stay [23, 63-65]. There are still ongoing trials for chloroquine/hydroxychloroquine preexposure and post-exposure prophylaxis, globally, including in Africa [61, 66]. Although the two drugs are widely available in sub-Saharan Africa because of their utility for treatment of malaria treatment, caution has been raised over their indiscriminate use for treatment of COVID-19 outside experimental or medically guided prescription [62].

More than 12 major manufacturers in Asia Pacific, Europe, North Africa, the Middle East and the Americas supply the global hydroxychloroquine market, but there are currently no manufacturers of the agent in subSaharan Africa [67]. India, the world's largest producer of hydroxychloroquine [67], initially banned exporting hydroxychloroquine to protect domestic demand in the wake of the pandemic, but giving emerging trial data on little impact of the drug in COVID-19 treatment, it lifted the ban in June 2020 [68]. Emerging observational, nonrandomized studies from African countries also indicate either no treatment or mortality effect [69], or possibly, a shortening of hospital stay compared to azithromycin or no treatment [70]. Regardless, access to hydroxychloroquine will be a challenge for sub-Saharan African countries if evidence should support its use in preventing COVID-19. Countries in the region are rising to the challenge, however: Cipla, a pharmaceutical company in Uganda announced its plan to start producing hydroxychloroquine in May 2020 [71]. The anticipated cost to patients is just $\$ 1$ per 14-day course, or approximately $\$ 0.07$ per day [72].

Also of interest is ivermectin, an antiparasitic used for the treatment of onchocerciasis, among other parasitic infections. It has in vitro efficacy against SARS-CoV-2 replication [ref], like it has against a broad spectrum of other RNA viruses [73, 74]. It is yet to be evaluated in a well-designed randomized control trial for its effectiveness in COVID-19 treatment, though the human trial dose required is 10,000 times larger than that used in cell culture, which makes it less likely to serve as a candidate for COVID-19 clinical trials [75]. However, if found effective at safe doses, the cost may not be prohibitive to African countries, as it is has been made available for free by manufacturer Merck \& Co. Inc. since 1987, and for as long as it was needed [76].

\section{Antibiotics}

Antibiotics used in the management of COVID-19 have been recommended specifically for treatment of suspected or confirmed bacterial superinfection [77]. However, macrolides such as azithromycin have been proposed to be used either alone or in combination with other drugs (eg hydroxychloroquine/chloroquine) for the primary treatment of COVID-19. However, there is still insufficient clinical trial evidence to substantiate this clinical application [78]. In in vitro studies, azithromycin has not been effective against SARS-CoV-2, but when combined with hydroxychloroquine, it inhibited viral replication [79]. Azithromycin may also be beneficial through its broad anti-inflammatory properties [80]. Evaluation of the effectiveness of azithromycin in clinical COVID-19 studies has been hampered by small numbers of study participants, methodological flaws and concerns about cardiotoxicity, especially in combination with chloroquine/hydroxychloroquine [65, 81, 82]. As such, there is insufficient clinical evidence for the use of azithromycin alone or in combination, in the treatment of COVID-19 [78, 80]. 


\section{Immunomodulators}

Associations between high expression of interleukin (IL)-1 andIL-6, and severe COVID-19 have been reported [83, 84]. Interferon beta-1a and inhibitors of IL-1 (anakinra) and IL-6 (sarilumab, siltuximab, tocilizumab) have been used as adjunct treatments for severe COVID-19 to ameliorate tissue damage caused by proinflammatory cytokines $[85,86]$. Observational/cohortstudies using IL-1 inhibitor anakinra [87, 88] and IL-6 inhibitor tocilizumab [89-92] have reported benefits in clinical improvements and survival. Clinical trials evaluating IL-1 and IL-6 inhibitors in COVID-19 are ongoing [93-95]. Results from the WHO Solidarity trial indicate that interferon beta-1a is not efficacious in reducing COVID-19 mortality [23]. The costs of immunomodulator infusions range from approximately $\$ 50$ (Canadian dollars) per day for $100 \mathrm{mg}$ of anakinra, and up to CAD $\$ 900$ per $400 \mathrm{mg}$ dose of tocilizumab [96]. Anakinra, tocilizumab and similar immunomodulatory agents are produced largely by Sweden Orphan Biovitrum, Regeneron Pharmaceuticals, EUSA Pharma, and Roche-all located in the global North [97-100].

The use of convalescent plasma (which is antibodyrich plasma from individuals who have recovered from a specific infection) and hyperimmune immunoglobulin (concentrated preparation of highly antibody-rich immunoglobulin) have been impactful in the treatment of severe viral respiratory diseases. COVID-19- specific convalescent plasma and hyperimmune globulin have been evaluated for treatment of SARS-CoV-2 infection in observational studies $[101,102]$ and randomized trials $[103,104]$. While some individual studies report benefits [101, 105, 106], an Indian trial [104] and multi-study analyses $[102,103,107]$ have been inconclusive with regard to impact on clinical improvement and mortality; the analyses cite small cohorts, weak/poor study design (including poor comparability of co-interventions) as contributing factors. Clearly, more data from rigorouslydesigned and large randomized trials are needed, and some of these are under way [108-110]. If found conclusively effective, convalescent plasma and hyperimmune globulin may be have good prospects for use in Africa due to the relative ease of preparation and storage of hyperimmune immunoglobulin from COVID-19 convalescent blood [111]. Even so, high costs of these treatments will be a potential barrier to access and scale-up.

\section{Traditional medicines and African compounds}

Amidst the flurry of new and repurposed drugs under investigation against SARS-CoV-2 infection, locally developed or locally obtained compounds from African countries have been presented as possible COVID-19 therapeutics. The Madagascar herbal tonic (branded Covid-Organics), developed by the Malagasy Institute of
Applied Research, is said to contain Artemisia annua, Cinnamomum camphora, essential oils, flavonoids, coumarins, polysaccharides, saponins, tannins, and pentacyclic triterpenes has been promoted as a cure for COVID-19 [112, 113], but it has not been tested against SARS-CoV-2 in vitro or in vivo. The World Health Organisation and Africa Centers for Disease Control have cautioned the public against the use of this as-yet unproven tonic and other untested herbal remedies [114, 115], however these two entities have convened a panel of experts who have developed a protocol and terms of reference for COVID-19 herbal medicine clinical trials [116] A recent preprint reports in vitro activity of Artemisia annua against SARS-CoV-2 [117], and the product has been listed for clinical testing, as reflected in Table 1.

NIPRIMUNE was developed as an immunostimulant by the National Institute for Pharmaceutical Research and Development Nigeria, and unveiled in 2018 as an adjunct treatment for HIV [118]. It is reported to have with potential as adjunct therapy for COVID-19 [119], but there is currently no clinical trial data available on its effectiveness against SARS-CoV-2 nor HIV.. In Ghana, the Center of Awareness CoA mixture (formerly CoA FS), is reported to contain 160 phytochemicals, and is commercially available as an immune booster supplement targeted for use by people living with HIV [120]. It is also being touted as immune support and treatment for COVID-19 symptoms and is reported to be undergoing safety and anti-viral efficacy studies at Ghana's Centre for Scientific Research into Plant Medicine [121]. A $250 \mathrm{ml}$ bottle of CoA mixture sells for approximately $\$ 21$; dosing is $10-20 \mathrm{mls}$ twice daily [120]. There is currently no clinical trial data on the effectiveness of CoA mixture against HIV or SARS-CoV-2. No related studies are registered in ClinicalTrials.gov, as reflected in Table 1.

\section{Other therapies}

Corticosteroids have historically not been recommended for treatment of viral pneumonias such as those caused by respiratory syncytial virus, influenza virus, the 2003 Severe Acute Respiratory Syndrome coronavirus, and Middle Eastern Respiratory Syndrome coronavirus,because of their lack of clinical effectiveness and risk of adverse effects [122, 123]. However, the United Kingdom's RECOVERY Trial found dexamethasone able to significantly reduce 28-day mortality among COVID-19 patients; by $18 \%$ among those requiring oxygen and by $36 \%$ for those on mechanical ventilation [24]. The lowest cost of a $4 \mathrm{mg} / \mathrm{ml}$ injectable solution of dexamethasone is $\sim 25$ for $25 \mathrm{ml}$ [124]. The 20 companies that supply dexamethasone globally are in seven countries (China, 
India, United States, Spain, Germany, France, Malaysia), none in sub-Saharan Africa [125].

The potential impact of dietary supplements such as vitamin $C$ and zinc, in decreasing the duration of COVID-19 symptoms and prevent disease progression in the ambulatory setting is being investigated. Additionally, on the heels of provocative findings in some observational studies [126-128], anticoagulant and antiplatelet therapies are being studied for use in patients with COVID-19 with rapidly deteriorating pulmonary, cardiac, or neurological function, or with sudden, localized loss of peripheral perfusion $[129,130]$.

\section{COVID-19 diagnostics}

Robust diagnostic testing to differentiate SARS-CoV-2 from other viral agents causing respiratory infections is needed. As a public health response, millions of cases and contacts must be tested in a timely manner to break the chain of transmission. The viral nucleic acid realtime reverse transcription-polymerase chain reaction (rRT-PCR) assay is the standard for the molecular diagnosis of COVID-19 [131]. Effective management of COVID-19 across countries is therefore dependent on a consistent supply of test kits and laboratory capacity to utilize them [132]. The immense demand for COVID-19 test kits has led to a global shortage, which has been worse in Africa, where countries who may have funds cannot procure the products because of supply shortages [133]. Pricing for COVID-19 testing varies widely globally, and even within countries, and thus these price variations will have to be better regulated as testing is scaled up beyond studies and state-level surveillance.

In response to the rapidly growing need for and the shortage of rRT-PCR assay kits, many diagnostic-test manufacturers are developing and supplying rapid-test kits to detect SARS-CoV-2 [134]. Rapid SARS-CoV-2 antigen detection tests can detect active infection, and antibody testing complements rtPCR, at about 10 or more days or more after symptom onset, in assessing past infections [135]. Immune-based assays for detecting human IgA, IgM and/ or IgG antibodies are also available [135]. Fortunately, COVID-19 diagnostics manufacturers include local African companies in Kenya, Morocco, Senegal, and South Africa [133]. Products from local manufacturers will help advance he Africa Centres for Disease Control and Prevention Partnership to Accelerate COVID-19 Testing (PACT): Test, Trace, Treat [136]. This initiative is mobilizing experts, community workers, suppliers, and other resources to test, trace, and treat COVID-19 in timely fashion, to minimize the impact of the pandemic in Africa.

\section{Discussion}

While the direct health impact of COVID-19 has not been as dire as expected [137, 138], sub-Saharan Africa is not yet adequately pandemic-prepared. Significant gaps exist in the pipeline and in access to critical commodities such as vaccines, therapeutics, and diagnostics. At the time of this publication, the World Health Organization has not declared an effective treatment for COVID-19, although dexamethasone is currently the only therapy that has shown conclusive benefits for the management of moderate to severe disease among hospitalised patients [23]. When effective drugs or regimens are identified for the management of mild, moderate and severe COVID-19, high-income countries may stockpile them for use by their citizens, while African countries will likely have difficulty procuring these commodities, similar to the current difficulty in procuring diagnostics. The investments of South Africa in hosting trials seven of the 18 vaccine trials in Africa - is noteworthy and a reflection of their leadership in HIV vaccine development efforts on the continent.

\section{Access to vaccines}

If proactive measures are not undertaken, sub-Saharan Africa may not be self-reliant for COVID-19 vaccines when they are developed. At this time, European and North American countries already have agreements with AstraZeneca to ensure that they have priority access to the University of Oxford COVID-19 vaccine under development for its citizens, if the vaccine is found to be effective $[139,140]$. It is encouraging, though, that partnerships between AstraZeneca, the Coalition for Epidemic Preparedness and Innovation, the Global Alliance for Vaccine and Immunisation, and the Serum Institute of India may facilitate equitable access to the Oxford vaccine through the COVID-19 Vaccine Global Access (COVAX) initiative [141]: COVAX aims to incentivize industry to make products available to all, regardless of ability to pay. The People's Vaccine campaign [142] and the World Health Organisation's COVID-19 Technology Access Pool [143] also are instruments that can increase access to vaccines in sub-Saharan Africa.

Sub-Saharan Africa has opportunities to address its low vaccine manufacturing capacity through the 20112020 Global Vaccine Action Plan, which provides universal access to critical vaccines through multiple approaches, including manufacturing [144]. The Plan is a roadmap for achieving the vision of the Decade of Vaccines through the transfer of vaccine manufacturing technology to African countries to enable them to meet their vaccine needs, including for emerging infectious diseases. For example, a call for implementation of the Plan was made at the 2015 World Health Assembly shortly after the 2014 Ebola outbreak in West Africa [144].

Preceding the Global Vaccine Action Plan, there was the Developing Countries Vaccine Manufacturers 
Network, established in 2000 to increase the production of high-quality vaccines; South Africa is the only member country from sub-Saharan Africa [145]. There is also the African Vaccine Manufacturing Initiative, established in 2010 to promote sustainable human-vaccine manufacturing capacity in Africa [146], and has the potential to be harnessed for the COVID-19 response. Unfortunately, these initiatives have been slow in galvanising support for implementation of their mandates. However, the Coalition for Epidemic Preparedness Innovations, a global initiative established in 2017 to accelerate vaccine development against emerging infectious diseases, has been raising funds to support COVID-19 vaccine research [147]. Like the COVID-19 Therapeutics Accelerator, the Coalition could facilitate access of countries in subSaharan Africa to COVID-19 vaccines developed elsewhere. If not already in process, it would be opportune for the Africa Centres for Disease Control and Prevention, in partnership with the African Union, have discussions with the Coalition to negotiate access.

\section{Access to therapeutics}

Historically, access to new and effective therapeutics has been a major challenge for African countries. Global production of therapeutics is frequently geared towards profitable Western markets and ill-adapted to African realities [148]. Africa accounts for only $3 \%$ of global medicinal drug manufacturing [149], and between 70 and 90\% of the medicines consumed in sub-Saharan African countries are imported [148]. For the entire continent, South Africa and Morocco are the exception, where 70 to $80 \%$ of pharmaceutical needs are met locally [149]. Only recently has Nigeria, the most populous African country, started addressing medicine access by providing loans to indigenous pharmaceutical companies and other organizations to support development of the pharmaceutical manufacturing sector, including pharmaceutical research and development [150].

Three factors that influence the access to medicines are availability, quality, and affordability. Improving availability of COVID-19 medicines in sub-Saharan Africa will depend on the sourcing and/or local manufacture of active pharmaceutical ingredients, most of which are manufactured in China or India [151]. Dexamethasone, so far the only active pharmaceutical ingredient conclusively proven effective for the treatment of moderate to severe COVID-19, is not manufactured in Africa. Quality medicines are also needed for interruption of COVID-19 transmission and mitigation of its morbidity and mortality. External sourcing also affects affordability and access, due to the costs and logistical hurdles of importation. Thus, barriers to access to finished pharmaceutical products needed for COVID-19 management must be reduced in sub-Saharan Africa, while the capacity for local production of medicines and diagnostics is expanded. In the short term, affordability, through better pricing, can be improved by pooling procurement of pharmaceutical products by the Africa Centers for Disease Control and Prevention in partnership with the African Union.

For long-term drug manufacturing in Africa, a harmonized regulatory system is needed to address the needs of member states. The African Medicines Regulatory Harmonization established by the New Partnership for Africa's Development is a comprehensive plan for regional regulatory approval for drugs on the continent, like that of the European Union [152]; it provides leadership in creating and enabling a favourable regulatory environment for pharmaceutical-sector development. Furthermore, countries and sub-regions can adopt the pharma parks approach, where indigenous pharmaceutical companies collaborate to build the infrastructure necessary for manufacture of both active pharmaceutical ingredients and finished pharmaceutical products, thereby driving down the cost of production and ultimately enhancing access as is being done in India [153155]. Also, support for development of industrial agricultural parks as source of raw materials such as pharmaceutical grade starch, sugar and ethanol for the pharma industries as in Ethiopia, is another way forward [156].

If clinical trial results support the deployment of new therapies, the continent may need to negotiate access to preventive or therapeutic COVID-19 interventions. Of note, South Africa and India have submitted a proposal to the World Trade Organization to consider waiving some intellectual property rules to allow for expedited access to COVID-19 vaccines and therapeutics [157]. Finally, it is imperative that negotiations, activities and studies to scale-up therapeutics and vaccines do not exclude pregnant women, children and youth, important subpopulations in the pandemic response in subSaharan Africa [158, 159].

\section{Access to diagnostics}

There is also need to drive local development of rapidtest kits and other diagnostics for COVID-19. The infrastructure developed/strengthened for the COVID-19 response can additionally be harnessed for the manufacture of drugs, vaccines, and diagnostics needed for management and control of other diseases in subSaharan Africa. The COVID-19 Therapeutic Accelerator, which is committed to ensuring that COVID-19 products are accessible to people in low-resource settings [160], also can assist in controlling costs. The collaboration between Africa CDC and the Foundation for Innovative New Diagnostics to build COVID-19 rapid diagnostic test capacity may fast-track the process of 
institutionalising diagnostics development capacity process using a South-South collaborative approach [161].

\section{Conclusion}

Several efforts are underway to discover, repurpose, and/ or develop preventive and treatment options for COVID-19. Sub-Saharan Africa's pharmaceutical industry is poorly developed and will not be able to expediently meet the region's prevention and treatment needs for the biomedical management of COVID-19. Lessons already learned from the pandemic underscore the need for the region to look inward and devote resources for the design, discovery, and deployment of vaccines, drugs, and diagnostic tests to meet current and future needs. This capacity- and infrastructure-building will be a crucial part of the response to the evolving COVID-19 pandemic and can be the base for effective and timely responses to future disease outbreaks.

\section{Abbreviations}

ARDS: Acute respiratory distress syndrome; COVID-19: Novel coronavirus disease 2019; CQ: Chloroquine; HCQ: Hydroxychloroquine; ICU: Intensive care unit; RR: Relative risk; SARS-CoV-2: Severe acute respiratory syndrome coronavirus 2

\section{Acknowledgements}

Not applicable.

\section{Disclaimer}

The views expressed are those of the authors and should not be construed to represent the positions of the U.S. Army or the Department of Defense.

\section{Authors' contributions}

$B B$ and MOF conceptualized the study. BB, CPB, NAS-A, AAO, AO, UA, POS, TAC, YKT, SP, NN and MOF collected and analysed the review articles. BB developed the first draft of the manuscript. CPB, NAS-A, AAO, AO, UA, POS, TAC, YKT, SP, NN and MOG contributed to the development of the full manuscript and agreed to the final version of the manuscript. All authors have read and approved the manuscript.

\section{Funding}

Not Applicable.

\section{Availability of data and materials}

The data used and analysed are all included in the manuscript.

\section{Ethics approval and consent to participate}

Not Applicable.

\section{Consent for publication}

Not applicable.

\section{Competing interests}

MOF is a Sectional Editor with BMC AIDS Research and Therapy. NN is the Editor of BMC AIDS Research and Therapy. All other authors declare that they have no competing interests.

\section{Author details}

${ }^{1}$ COVID-19 Think Tank, Nigeria. ${ }^{2}$ Live Well Initiative Academy Nigeria, Lagos, Nigeria. ${ }^{3}$ Department of Pharmaceutical Chemistry, Faculty of Pharmacy, University of Ibadan, Ibadan, Nigeria. ${ }^{4}$ Centre for Drug Discovery, Development \& Production, University of Ibadan, Ibadan, Nigeria. ${ }^{5}$ Genetics \& Bioethics Unit, Institute of Advanced Medical Research \& Training, College of Medicine, Ibadan, Nigeria. ${ }^{6}$ College of Basic Medical Sciences, Chrisland
University, Abeokuta, Ogun State, Nigeria. ${ }^{7}$ Institute of Human Virology Nigeria, Abuja, Nigeria. ${ }^{8}$ Institute of Human Virology, University of Maryland School of Medicine, Baltimore, USA. ${ }^{9}$ Department of Paediatrics, University of Cape Coast School of Medical Sciences, Cape Coast, Ghana. ${ }^{10}$ Unit of Clinical Chemistry, Department of Medical Laboratory Science, University College Hospital, Ibadan, Nigeria. "'Unit of Clinical Chemistry, Department of Medical Laboratory Science, Lead City University, Ibadan, Nigeria. ${ }^{12}$ Fort Worth Internal Medicine, Fort Worth, TX, USA. ${ }^{13}$ World Health Organisation, Asaba, Delta State, Nigeria. ${ }^{14}$ Stephen's Pedi \& Pulmonary Medicine, Fort Worth, TX, USA. ${ }^{15}$ U.S. Military HIV Research Program, Walter Reed Army Institute of Research, Silver Spring, MD, USA. ${ }^{16}$ Henry M. Jackson Foundation for the Advancement of Military Medicine, Bethesda, MD, USA. ${ }^{17}$ Africa Center for Disease Control and Prevention, African Union Commission, Addis Ababa, Ethiopia. ${ }^{18}$ Kanazawa University, Graduate School of Medical Sciences, Kanazawa, Japan. ${ }^{19}$ Department of Child Dental Health, Obafemi Awolowo University, lle-lfe, Nigeria.

Received: 10 July 2020 Accepted: 4 February 2021

Published online: 03 March 2021

\section{References}

1. Dong E, Du H, Gardner L. An interactive web-based dashboard to track COVID-19 in real time. Lancet Infect Dis. 2020;20(5):533-4.

2. El-Sadr WM, Justman J. Africa in the path of Covid-19. N Engl J Med. 2020; 383(3):e11.

3. Gilbert M, Pullano G, Pinotti F, Valdano E, Poletto C, Boëlle PY, et al. Preparedness and vulnerability of African countries against importations of COVID-19: a modelling study. Lancet. 2020;395(10227):871-7.

4. Paintsil E. COVID-19 threatens health systems in sub-Saharan Africa: the eye of the crocodile. J Clin Invest. 2020;130(6):2741-4.

5. Nachega J, Seydi M, Zumla A. The late arrival of coronavirus disease 2019 (COVID-19) in Africa: mitigating Pan-continental spread. Clin Infect Dis. 2020; 71(15):875-8.

6. Farrell TW, Francis L, Brown T, Ferrante LE, Widera E, Rhodes R, et al. Rationing limited healthcare resources in the COVID-19 era and beyond: ethical considerations regarding older adults. J Am Geriatr Soc. 2020;68(6): $1143-9$.

7. Jessop ZM, Dobbs TD, Ali SR, Combellack E, Clancy R, Ibrahim N, et al. Personal protective equipment (PPE) for surgeons during COVID-19 pandemic: a systematic review of availability, usage, and rationing. Br J Surg. 2020;107(10):1262-80.

8. Rosenbaum L. Facing Covid-19 in Italy - ethics, logistics, and therapeutics on the Epidemic's front line. N Engl J Med. 2020;382(20):1873-5.

9. White DB, Lo B. A framework for rationing ventilators and critical care beds during the COVID-19 pandemic. Jama. 2020;323(18):1773-4.

10. Nachega JB, Grimwood A, Mahomed H, Fatti G, Preiser W, Kallay O, et al. From easing lockdowns to scaling-up community-based COVID-19 screening, testing, and contact tracing in Africa - shared approaches, innovations, and challenges to minimize morbidity and mortality. Clin Infect Dis. 2020;ciaa695.

11. Africa Centers for Disease Control. Guidance for Assessment, Monitoring, and Movement Restrictions of People at Risk for COVID-19 in Africa 2020 [Available from: https://africacdc.org/download/africa-cdc-guidance-for-a ssessment-monitoring-and-movement-restrictions-of-people-at-risk-forcovid-19-in-africa/?ind=15844463763558filename=Assessment-MonitoringMovement-Restrictions-COVID-19-Africa.pdf\&wpdmdl=3456\&refresh=5fa3 5b68eead81604541288. Accessed: 29 Oct 2020.

12. Hellewell J, Abbott S, Gimma A, Bosse NI, Jarvis Cl, Russell TW, et al. Feasibility of controlling COVID-19 outbreaks by isolation of cases and contacts. Lancet Glob Health. 2020;8(4):e488-e96.

13. ClinicalTrials.gov. COVID-19 Vaccine Trials. 2020 [Available from: https:// clinicaltrials.gov/ct2/results? recrs $=$ ab\&type $=$ Intr\&cond=Covid $19 \&$ intr $=\% 22 \mathrm{Va}$ ccines\%22. Accessed: 5 Nov 2020].

14. Folegatti PM, Ewer KJ, Aley PK, Angus B, Becker S, Belij-Rammerstorfer S, et al. Safety and immunogenicity of the ChAdOx $1 \mathrm{nCoV}-19$ vaccine against SARS-CoV-2: a preliminary report of a phase $1 / 2$, single-blind, randomised controlled trial. Lancet. 2020;396(10249):467-78.

15. Anderson EJ, Rouphael NG, Widge AT, Jackson LA, Roberts PC, Makhene M, et al. Safety and immunogenicity of SARS-CoV-2 mRNA-1273 vaccine in older adults. N Engl J Med. 2020;383(25):2427-38. 
16. Zhu FC, Li YH, Guan XH, Hou LH, Wang WJ, Li JX, et al. Safety, tolerability, and immunogenicity of a recombinant adenovirus type- 5 vectored COVID19 vaccine: a dose-escalation, open-label, non-randomised, first-in-human trial. Lancet. 2020;395(10240):1845-54.

17. Bhattacharya R, Chowdhury S, Mukherjee R, Nandi A, Kulshrestha M, Ghosh R, et al. Pre exposure hydroxychloroquine prophylaxis for covid-19 in healthcare workers: a retrospective cohort. medRxiv. 2020; 2020.06.09.20116806.

18. Boulware DR, Pullen MF, Bangdiwala AS, Pastick KA, Lofgren SM, Okafor EC, et al. A randomized trial of hydroxychloroquine as Postexposure prophylaxis for Covid-19. N Engl J Med. 2020;383(6):517-25.

19. Cuadrado-Lavín A, Olmos JM, Cifrian JM, Gimenez T, Gandarillas MA, GarcíaSaiz M, et al. Controlled, double-blind, randomized trial to assess the efficacy and safety of hydroxychloroquine chemoprophylaxis in SARS CoV2 infection in healthcare personnel in the hospital setting: a structured summary of a study protocol for a randomised controlled trial. Trials. 2020;21(1):472.

20. Beigel JH, Tomashek KM, Dodd LE, Mehta AK, Zingman BS, Kalil AC, et al. Remdesivir for the treatment of Covid-19 - final report. N Engl J Med. 2020; 383(19):1813-26.

21. Grein J, Ohmagari N, Shin D, Diaz G, Asperges E, Castagna A, et al. Compassionate use of Remdesivir for patients with severe Covid-19. N Engl J Med. 2020;382(24):2327-36

22. Wang Y, Zhang D, Du G, Du R, Zhao J, Jin Y, et al. Remdesivir in adults with severe COVID-19: a randomised, double-blind, placebo-controlled, multicentre trial. Lancet. 2020;395(10236):1569-78.

23. Pan H, Peto R, Karim QA, Alejandria M, Henao-Restrepo AM, García CH, et al. Repurposed antiviral drugs for COVID-19 -interim WHO SOLIDARITY trial results. medRxiv. 2021;384(6):497-511.

24. Horby P, Lim WS, Emberson JR, Mafham M, Bell JL, Linsell L, et al. Dexamethasone in hospitalized patients with Covid-19 - preliminary report. N Engl J Med. 2020;NEJMoa2021436.

25. ClinicalTrials.gov NCT04379336. Reducing Morbidity and Mortality in Health Care Workers Exposed to SARS-CoV-2 by Enhancing Non-specific Immune Responses Through Bacillus Calmette-Guérin Vaccination, a Randomized Controlled Trial 2020 [Available from: https://clinicaltrials.gov/ct2/show/ NCT04379336? recrs=ab\&cond=Covid19\&cntry=ZA\&draw=2\&rank=4. Accessed: 5 Nov 2020.

26. GeurtsvanKessel CH, Okba NMA, Igloi Z, Bogers S, Embregts CWE, Laksono $\mathrm{BM}$, et al. An evaluation of COVID-19 serological assays informs future diagnostics and exposure assessment. Nat Commun. 2020;11(1):3436.

27. Soliman R, Brassey J, Plüddemann A, Heneghan C. Does BCG vaccination protect against acute respiratory infections and COVID-19? A rapid review of current evidence 2020. [Available from: https://www.cebm.net/covid-19/ does-bcg-vaccination-protect-against-acute-respiratory-infections-andcovid-19-a-rapid-review-of-current-evidence/. Accessed: 5 Nov 2020.

28. Curtis N, Sparrow A, Ghebreyesus TA, Netea MG. Considering BCG vaccination to reduce the impact of COVID-19. Lancet. 2020;395(10236):1545-6.

29. NCT04384549 Cg. Efficacy of BCG Vaccination in the Prevention of COVID19 Via the Strengthening of Innate Immunity in Health Care Workers (COVIDBCG) 2020 [Available from: https://clinicaltrials.gov/ct2/show/NCT04384549. Accessed: 20 June 2020.

30. Gopalaswamy R, Ganesan N, Velmurugan K, Aravindhan V, Subbian S. The strange case of BCG and COVID-19: the verdict is still up in the air. Vaccines (Basel). 2020;8(4):612

31. Nemes E, Geldenhuys H, Rozot V, Rutkowski KT, Ratangee F, Bilek N, et al. Prevention of $M$. tuberculosis infection with $\mathrm{H} 4: \mathrm{IC} 31$ vaccine or $B C G$ revaccination. N Engl J Med. 2018;379(2):138-49.

32. Biering-Sørensen S, Aaby P, Lund N, Monteiro I, Jensen KJ, Eriksen HB, et al. Early BCG-Denmark and neonatal mortality among infants weighing $<2500$ g: a randomized controlled trial. Clin Infect Dis. 2017;65(7):1183-90.

33. de Chaisemartin C, de Chaisemartin L. BCG vaccination in infancy does not protect against COVID-19. Evidence from a natural experiment in Sweden. Clin Infect Dis. 2020:ciaa1223.

34. ClinicalTrials.gov NCT04444674. COVID-19 Vaccine (ChAdOx1 nCoV-19) Trial in South African Adults with and without HIV-infection 2020 [Available from: https:/clinicaltrials.gov/ct2/show/NCT04444674?term=Vaccine\&cond= Covid-19\&cntry=ZA\&draw=2\&rank=2. Accessed: 5 Nov 2020 ].

35. ClinicalTrials.gov NCT04553016. A Phase 1 Trial of ChAdOx1- and MVAvectored Conserved Mosaic HIV-1 Vaccines in Healthy, Adult HIV-1-negative Volunteers in Eastern and Southern Africa. 2020 [Available from: https:// clinicaltrials.gov/ct2/show/NCT04553016?term=ChAdOx1\&map cntry= KE\&draw $=2 \&$ rank=1]. Accessed: 5 Nov 2020.
36. Makoni M. COVID-19 vaccine trials in Africa. Lancet Respir Med. 2020;8(11): e79-80.

37. World Health Organization. Q\&A on the Phase 3 trial results for malaria vaccine RTS,S/AS01 2017 [Available from: https://www.who.int/malaria/ media/rtss-phase-3-trial-qa/en/. Accessed: 5 Nov 2020.

38. Mugerwa RD, Kaleebu $P$, Mugyenyi $P$, Katongole-Mbidde E, Hom DL, Byaruhanga $\mathrm{R}$, et al. First trial of the HIV-1 vaccine in Africa: Ugandan experience. Bmj. 2002;324(7331):226-9.

39. Tameris M, McShane H, McClain JB, Landry B, Lockhart S, Luabeya AK, et al. Lessons learnt from the first efficacy trial of a new infant tuberculosis vaccine since BCG. Tuberculosis (Edinb). 2013;93(2):143-9.

40. Henao-Restrepo AM, Camacho A, Longini IM, Watson CH, Edmunds WJ, Egger $M$, et al. Efficacy and effectiveness of an rVSV-vectored vaccine in preventing Ebola virus disease: final results from the Guinea ring vaccination, open-label, cluster-randomised trial (Ebola Ça Suffit!). Lancet. 2017;389(10068):505-18.

41. Laher F, Bekker LG, Garrett N, Lazarus EM, Gray GE. Review of preventative HIV vaccine clinical trials in South Africa. Arch Virol. 2020;165(11):2439-52.

42. Lhomme E, Modet C, Augier A, Faye S, Dabakuyo-Yonli TS, Levy-Marchal C, et al. Enrolling study personnel in Ebola vaccine trials: from guidelines to practice in a non-epidemic context. Trials. 2019;20(1):422.

43. Innovative Medicines Initiative. Trial of second Ebola vaccine to start in Democratic Republic of the Congo. 2019 October 31. [Available from: https://www.imi.europa.eu/news-events/newsroom/trial-second-ebola-va ccine-start-democratic-republic-congo. Accessed: 5 Nov 2020].

44. Ampofo W. Vaccine manufacturing in Africa: Self-sufficiency-a need? Or a dream? No date. [Available from: https://www.who.int/immunization/resea rch/forums_and_initiatives/1_Wlliam_Ampofo_Vaccine_Manufacturing_A frica.pdf?ua=1. Accessed: 5 Nov 2020].

45. Nkengasong JN, Ndembi N, Tshangela A, Raji T. COVID-19 vaccines: how to ensure Africa has access. Nature. 2020;586(7828):197-9.

46. Choy KT, Wong AY, Kaewpreedee P, Sia SF, Chen D, Hui KPY, et al. Remdesivir, lopinavir, emetine, and homoharringtonine inhibit SARS-CoV-2 replication in vitro. Antivir Res. 2020;178:104786.

47. Wang M, Cao R, Zhang L, Yang X, Liu J, Xu M, et al. Remdesivir and chloroquine effectively inhibit the recently emerged novel coronavirus (2019-nCoV) in vitro. Cell Res. 2020;30(3):269-71.

48. Dong L, Hu S, Gao J. Discovering drugs to treat coronavirus disease 2019 (COVID-19). Drug Discov Ther. 2020;14(1):58-60.

49. Brown AJ, Won JJ, Graham RL, Dinnon KH 3rd, Sims AC, Feng JY, et al. Broad spectrum antiviral remdesivir inhibits human endemic and zoonotic deltacoronaviruses with a highly divergent RNA dependent RNA polymerase. Antivir Res. 2019;169:104541.

50. Li Y, Xie Z, Lin W, Cai W, Wen C, Guan Y, et al. Efficacy and safety of Lopinavir/ritonavir or Arbidol in adult patients with mild/moderate COVID-19: an exploratory randomized controlled trial. Med (N Y). 2020; 1(1):105-13.e4.

51. Doward J, Gbinigie K. Lopinavir/ritonavir: A rapid review of effectiveness in COVID-19 2020 April 14. [Available from: https://www.cebm.net/covid-19/ lopinavir-ritonavir-a-rapid-review-of-the-evidence-for-effectiveness-in-trea ting-covid/. Accessed: 5 Nov 2020].

52. Baroutjian A, Sanchez C, Boneva D, McKenney M, Elkbuli A. SARS-CoV-2 pharmacologic therapies and their safety/effectiveness according to level of evidence. Am J Emerg Med. 2020;38(11):2405-15.

53. Shiraki K, Daikoku T. Favipiravir, an anti-influenza drug against lifethreatening RNA virus infections. Pharmacol Ther. 2020;209:107512.

54. Chen C, Zhang Y, Huang J, Yin P, Cheng Z, Wu J, et al. Favipiravir versus Arbidol for COVID-19: a randomized clinical trial. medRxiv. 2020.

55. US Food and Drug Administration. Coronavirus (COVID-19) update: FDA issues emergency use authorization for potential COVID-19 treatment. 2020 [Available from: https://www.fda.gov/news-events/press-announcements/ coronavirus-covid-19-update-fda-issues-emergency-use-authorizationpotential-covid-19-treatment. Accessed: 26 June 2020].

56. The Times of India. India approves emergency use of remdesivir to treat COVID-19 2020 June 2. [Available from: https://timesofindia.indiatimes.com/ india/india-approves-emergency-use-of-remdesivir-to-treat-covid-19-pa tients/articleshow/76152949.cms. Accessed: 5 Nov 2020].

57. Reuters. Singapore approves remdesivir drug for emergency COVID-19 treatment 2020 June 10. [Available from: https://www.reuters.com/article/ushealth-coronavirus-singapore-remdesiv/singapore-approves-remdesivir-drugfor-emergency-covid-19-treatment-idUSKBN23H17F. Accessed: 5 Nov 2020]. 
58. The Asahi Shimbun. Japan approves remdesivir for COVID-19 despite uncertainties 2020 May 8. [Available from: http://www.asahi.com/ajw/a rticles/13358075. Accessed: 5 Nov 2020].

59. Dyer O. Covid-19: Remdesivir has little or no impact on survival, WHO trial shows. Bmj. 2020;371:m4057.

60. Bloomberg. Gilead Chooses Middle Ground in Pricing of Its Coronavirus Drug 2020 June 29. [Available from: https://www.bloomberg.com/news/a rticles/2020-06-29/gilead-says-remdesivir-will-cost-2-340-for-five-day-trea tment. Accessed: 5 Nov 2020.

61. ClinicalTrials.gov. COVID-19 Trials Evaluating Chloroquine as Pre- or PostExposure Prevention 2020 [Available from: https://clinicaltrials.gov/ct2/ results?cond $=$ Covid19\&term $=$ prophylaxis\&type $=\& r s l t=\&$ recrs $=b \& r e c r s=a \& a$ ge_v=\&gndr=\&intr=\%22chloroquine\%22\&titles=\&outc=\&spons=\&lead=\&id = $\&$ cntry $=\&$ state $=\& c i t y=\& d i s t=\& l o c n=\& r s u b=\& s t r d \_s=\& s t r d \_e=\& p r c d \_s=$ \&prcd_e=\&sfpd_s=\&sfpd_e=\&rfpd_s=\&rfpd_e=\&lupd_s=\&lupd_e=\&sort=. Accessed: 7 Nov 2020]

62. Abena PM, Decloedt EH, Bottieau E, Suleman F, Adejumo P, Sam-Agudu NA, et al. Chloroquine and hydroxychloroquine for the prevention or treatment of COVID-19 in Africa: caution for inappropriate off-label use in healthcare settings. Am J Trop Med Hyg. 2020;102(6):1184-8.

63. Horby P, Mafham M, Linsell L, Bell JL, Staplin N, Emberson JR, et al. Effect of hydroxychloroquine in hospitalized patients with COVID-19: preliminary results from a multi-Centre, randomized, controlled trial. medRxiv. N Engl J Med. 2020;383(21):2030-40.

64. Cavalcanti AB, Zampieri FG, Rosa RG, Azevedo LCP, Veiga VC, Avezum A, et al. Hydroxychloroquine with or without azithromycin in mild-tomoderate Covid-19. N Engl J Med. 2020;383(21):2041-52.

65. Ayele Mega T, Feyissa TM, Dessalegn Bosho D, Kumela Goro K, Zeleke NG. The outcome of hydroxychloroquine in patients treated for COVID-19: systematic review and meta-analysis. Can Respir J. 2020;2020:4312519.

66. ClinicalTrials.gov. COVID-19 Trials Evaluating Hydroxychloroquine as Pre- or Post-Exposure Prevention 2020 [Available from: https://clinicaltrials.gov/ct2/ results?term $=$ prophylaxis\&recrs $=$ ab\&cond $=$ Covid $19 \&$ int $=\% 22$ Hydroxychloroquine\%22. Accessed: 7 Nov 2020].

67. Zhang TY, Zhong B. Meeting the potential emergency global drug supply challenge of hydroxychloroquine for COVID-19. Med Drug Discov. 2020;5: 100036.

68. The Hindu. India lifts export ban on hydroxychloroquine 2020 June 11 [Available from: https://www.thehindu.com/news/national/india-lifts-exportban-on-hydroxychloroquine/article31806635.ece. Accessed: 5 Nov 2020].

69. Nachega JB, Ishoso DK, Otokoye JO, Hermans MP, Machekano RN, SamAgudu NA, et al. Clinical characteristics and outcomes of patients hospitalized for COVID-19 in Africa: early insights from the Democratic Republic of the Congo. Am J Trop Med Hyg. 2020;103(6):2419-28.

70. Ashinyo M, Duti V, Dubik S, Amegah K, Kutsoati K, Oduro-Mensah E, et al. Clinical characteristics, treatment regimen and duration of hospitalization among COVID-19 patients in Ghana: a retrospective cohort study. Pan Afr Med J. 2020;37(Suppl 1):9.

71. The East African. Uganda's Cipla takes bold step to make 'unpopular' malaria drug 2020 [Available from: https://www.theeastafrican.co.ke/ business/Uganda-Cipla-to-make-malaria-drug/2560-5549874-v6f1 hpz/index. html. Accessed: 5 Nov2 020 ].

72. Hill A, Wang J, Levi J, Heath K, Fortunak J. Minimum costs to manufacture new treatments for COVID-19. J Virus Erad. 2020;6(2):61-9.

73. Sharun K, Dhama K, Patel SK, Pathak M, Tiwari R, Singh BR, et al. Ivermectin, a new candidate therapeutic against SARS-CoV-2/COVID-19. Ann Clin Microbiol Antimicrob. 2020;19(1):23.

74. Caly L, Druce JD, Catton MG, Jans DA, Wagstaff KM. The FDA-approved drug ivermectin inhibits the replication of SARS-CoV-2 in vitro. Antivir Res. 2020;178:104787.

75. Bray M, Rayner C, Noël F, Jans D, Wagstaff K. Ivermectin and COVID-19: a report in antiviral research, widespread interest, an FDA warning, two letters to the editor and the authors' responses. Antivir Res. 2020;178: 104805.

76. World Health Organization. African Programme for Onchocerciasis Control (APOC) 2020 [Available from: https://www.who.int/apoc/cdti/ivermectin/en/. Accessed: 5 Nov 2020].

77. World Health Organization. Clinical management of COVID-19: interim guidance 2020 [Available from: https://www.who.int/publications/i/item/ clinical-management-of-covid-19. Accessed: 5 Nov 2020].
78. Gbinigie K, Frie K. What is the evidence for using macrolide antibiotics to treat COVID-19? 2020 [Available from: https://www.cebm.net/covid-19/whatis-the-evidence-for-use-of-macrolide-antobiotics-for-treatmetnof-covid-19/. Accessed: 5 Nov 2020].

79. Andreani J, Le Bideau M, Duflot I, Jardot P, Rolland C, Boxberger M, et al. In vitro testing of combined hydroxychloroquine and azithromycin on SARSCoV-2 shows synergistic effect. Microb Pathog. 2020;145:104228.

80. Oliver ME, Hinks TSC. Azithromycin in viral infections. Rev Med Virol. 2020: e2163.

81. Ramireddy A, Chugh H, Reinier K, Ebinger J, Park E, Thompson M, et al. Experience with hydroxychloroquine and azithromycin in the coronavirus disease 2019 pandemic: implications for QT interval monitoring. J Am Heart Assoc. 2020;9(12):e017144.

82. Shah RR. Chloroquine and hydroxychloroquine for COVID-19: perspectives on their failure in repurposing. J Clin Pharm Ther. 2021;46(1):17-27.

83. Wu C, Chen X, Cai Y, Xia J, Zhou X, Xu S, et al. Risk factors associated with acute respiratory distress syndrome and death in patients with coronavirus disease 2019 pneumonia in Wuhan, China. JAMA Intern Med. 2020;180(7): 934-43.

84. Huang C, Wang Y, Li X, Ren L, Zhao J, Hu Y, et al. Clinical features of patients infected with 2019 novel coronavirus in Wuhan, China. Lancet. 2020;395(10223):497-506.

85. Sinha P, Matthay MA, Calfee CS. Is a "cytokine storm" relevant to COVID-19? JAMA Intern Med. 2020;180(9):1152-4.

86. Khan NA. Anakinra for severe forms of COVID-19. Lancet Rheumatol. 2020; 2(10):e586-e7

87. Cavalli G, De Luca G, Campochiaro C, Della-Torre E, Ripa M, Canetti D, et al. Interleukin-1 blockade with high-dose anakinra in patients with COVID-19, acute respiratory distress syndrome, and hyperinflammation: a retrospective cohort study. Lancet Rheumatol. 2020;2(6):e325-e31.

88. Huet T, Beaussier H, Voisin O, Jouveshomme S, Dauriat G, Lazareth I, et al. Anakinra for severe forms of COVID-19: a cohort study. Lancet Rheumatol. 2020;2(7):e393-400.

89. Xu X, Han M, Li T, Sun W, Wang D, Fu B, et al. Effective treatment of severe COVID-19 patients with tocilizumab. Proc Natl Acad Sci U S A. 2020;117(20): 10970-5.

90. Morrison AR, Johnson JM, Griebe KM, Jones MC, Stine JJ, Hencken LN, et al. Clinical characteristics and predictors of survival in adults with coronavirus disease 2019 receiving tocilizumab. J Autoimmun. 2020;114:102512.

91. Toniati P, Piva S, Cattalini M, Garrafa E, Regola F, Castelli F, et al. Tocilizumab for the treatment of severe COVID-19 pneumonia with hyperinflammatory syndrome and acute respiratory failure: a single center study of 100 patients in Brescia, Italy. Autoimmun Rev. 2020;19(7):102568.

92. Antwi-Amoabeng D, Kanji Z, Ford B, Beutler BD, Riddle MS, Siddiqui F. Clinical outcomes in COVID-19 patients treated with tocilizumab: an individual patient data systematic review. J Med Virol. 2020;92(11): 2516-22.

93. Rilinger J, Kern W, Duerschmied D, Supady A, Bode C, Staudacher DL, et al. A prospective, randomised, double blind placebo-controlled trial to evaluate the efficacy and safety of tocilizumab in patients with severe COVID-19 pneumonia (TOC-COVID): a structured summary of a study protocol for a randomised controlled trial. Trials. 2020;21(1):470.

94. Cotter A, Wallace D, McCarthy C, Feeney E, O'Neill L, Stack J, et al. The COVIRL002 trial-tocilizumab for management of severe, non-critical COVID19 infection: a structured summary of a study protocol for a randomised controlled trial. Trials. 2020;21(1):758.

95. Maes B, Bosteels C, De Leeuw E, Declercq J, Van Damme K, Delporte A, et al. Treatment of severely ill COVID-19 patients with anti-interleukin drugs (COV-AID): a structured summary of a study protocol for a randomised controlled trial. Trials. 2020;21(1):468.

96. Canadian Agency for Drugs and Technologies in Health. Tocilizumab (Actemra): adult patients with moderately to severely active rheumatoid arthritis. Table 1: cost-comparison table for biologic disease-modifying drugs for rheumatoid arthritis. 2015 [Available from: https://www.ncbi.nlm.nih.gov/ books/NBK349513/table/T43/. Accessed: 6 Nov 2020].

97. Roche Pharmaceuticals. Our Product List. 2020. [Available from: https:// www.roche.com/products/products-list $\sim$ division=pharmaceuticals $\sim$.htm. Accessed: 6 Nov 2020].

98. EUSA Pharma. Our Products. 2020. [Available from: https://eusapharma.com/ our-focus/our-products. Accessed: 6 Nov 2020]. 
99. Regeneron. Medicines. 2020. [Available from: https:/www.regeneron.com/ medicines/. Accessed: 6 Nov 2020].

100. Sweden Orphan Biovitrum. SOBI products. 2020. [Available from: https:/ www.sobi.com/en/products. Accessed: 6 Nov 2020].

101. Liu STH, Lin HM, Baine I, Wajnberg A, Gumprecht JP, Rahman F, et al. Convalescent plasma treatment of severe COVID-19: a propensity scorematched control study. Nat Med. 2020. https://doi.org/10.1038/s41591-020-1 088-9.

102. Valk SJ, Piechotta V, Chai KL, Doree C, Monsef I, Wood EM, et al. Convalescent plasma or hyperimmune immunoglobulin for people with COVID-19: a rapid review. Cochrane Database Syst Rev. 2020;5(5):Cd013600.

103. Piechotta V, Chai KL, Valk SJ, Doree C, Monsef I, Wood EM, Lamikanra A, Kimber C, McQuilten Z, So-Osman C, Estcourt L, Skoetz N. Convalescent plasma or hyperimmune immunoglobulin for people with COVID-19: a living systematic review. Cochrane Database Syst Rev. 2020;7(7):CD013600.

104. Agarwal A, Mukherjee A, Kumar G, Chatterjee P, Bhatnagar T, Malhotra P. Convalescent plasma in the management of moderate covid-19 in adults in India: open label phase II multicentre randomised controlled trial (PLACID trial). Bmj. 2020;371:m3939.

105. Schwartz SP, Thompson P, Smith M, Lercher DM, Rimland CA, Bartelt L, et al. Convalescent plasma therapy in four critically ill pediatric patients with coronavirus disease 2019: a case series. Crit Care Explor. 2020;2(10):e0237.

106. Shen C, Wang Z, Zhao F, Yang Y, Li J, Yuan J, et al. Treatment of 5 critically ill patients with COVID-19 with convalescent plasma. Jama. 2020;323(16): 1582-9.

107. Bakhtawar N, Usman M, Khan MMU. Convalescent plasma therapy and its effects on COVID-19 patient outcomes: a systematic review of current literature. Cureus. 2020;12(8):e9535.

108. Chowdhury FR, Hoque A, Chowdhury FUH, Amin MR, Rahim A, Rahman MM, et al. Convalescent plasma transfusion therapy in severe COVID-19 patients- a safety, efficacy and dose response study: a structured summary of a study protocol of a phase II randomized controlled trial. Trials. 2020; 21(1):883.

109. Janssen M, Schäkel U, Djuka Fokou C, Krisam J, Stermann J, Kriegsmann K, et al. A randomized open label phase-II clinical trial with or without infusion of plasma from subjects after convalescence of SARS-CoV-2 infection in high-risk patients with confirmed severe SARS-COV-2 disease (RECOVER): a structured summary of a study protocol for a randomised controlled trial. Trials. 2020;21(1):828.

110. Eckhardt CM, Cummings MJ, Rajagopalan KN, Borden S, Bitan ZC, Wolf A, et al. Evaluating the efficacy and safety of human anti-SARS-CoV-2 convalescent plasma in severely ill adults with COVID-19: a structured summary of a study protocol for a randomized controlled trial. Trials. 2020 21(1):499.

111. Kreil TR, Mc Vey JK, Lei LS, Camacho L, Wodal W, Kerschbaum A, et al. Preparation of commercial quantities of a hyperimmune human intravenous immunoglobulin preparation against an emerging infectious disease: the example of pandemic H1N1 influenza. Transfusion. 2012;52(4):803-9.

112. Nordling L. Unproven herbal remedy against COVID-19 could fuel drugresistant malaria, scientists warn. Science Magazine. May 6 2020. Available at: https:/www.sciencemag.org/news/2020/05/unproven-herbalremedy-againstcovid-19-could-fuel-drug-resistant-malaria-scientists. Accessed 18 Feb 2021.

113. Wikipedia. Covid-organics. 2020. [Available from: https://en.wikipedia.org/ wiki/Covid-Organics. Accessed: 6 Nov 2020].

114. World Health Organization. WHO supports scientifically-proven traditional medicine 2020 [Available from: https://www.afro.who.int/news/whosupports-scientifically-proven-traditional-medicine?gclid=CjOKCQjw-_j1 BRDKARIsAJcfmTFgtLJOcQKMB6h50oeZ4sU_q512Xy80tI-Vrf-_ XFSQpMlcGpblUDlaAqu6EALw_wcB. Accessed: 6 Nov 2020].

115. Africa Centres for Disease Control and Prevention. Statement on herbal remedies and medicines for prevention and treatment of COVID-19. 2020 [Available from: https://africacdc.org/download/statement-on-herbalremedies-and-medicines-for-prevention-and-treatment-of-covid-19/. Accessed: 6 Nov 2020].

116. World Health Organization. Expert panel endorses protocol for COVID-19 herbal medicine clinical trials. 2020 [Available from: https://www.afro.who. int/news/expert-panel-endorses-protocol-covid-19-herbal-medicine-clinicaltrials. Accessed: 6 Nov 2020].

117. Gilmore K, Zhou Y, Ramirez S, Pham LV, Fahnøe U, Feng S, et al. In vitro efficacy of artemisinin-based treatments against SARS-CoV-2. bioRxiv. 2020; 2020.10.05.326637.
118. Xinhuanet News. Nigeria unveils drugs for treatment of Ebola, malaria 2018 [Available from: http://www.xinhuanet.com/english/2018-01/20/c_1369092 97.htm. Accessed: 6 Nov 2020.

119. Obayendo T. Breaking: NIPRD develops NIPRIMUNE for COVID-19 treatment: PharmaNews Online; 27 May 2020. Available at: https://www.pharma newsonline.com/breaking-niprd-develops-niprimune-for-covid-19-trea tment/. Accessed 18 Feb 2021.

120. The Center of Awareness Food Supplement. CoA Mixture 2020 [Available from: https://www.coadrugs.org/coamixture/. Accessed: 6 Nov 2020].

121. AllAfrica.com. Ghana: COA FS, 8 Other Herbal Products Recommended As Immune Support, Treatment of COVID-19 2020 May 22 [Available from: https://allafrica.com/stories/202005220607.html. Accessed: 6 Nov 2020.

122. Li H, Chen C, Hu F, Wang J, Zhao Q, Gale RP, et al. Impact of corticosteroid therapy on outcomes of persons with SARS-CoV-2, SARS-CoV, or MERS-COV infection: a systematic review and meta-analysis. Leukemia. 2020;34(6):1503-11.

123. Russell CD, Millar JE, Baillie JK. Clinical evidence does not support corticosteroid treatment for 2019-nCoV lung injury. Lancet. 2020;395(10223): $473-5$.

124. Drugs.com. Dexamethasone prices, coupons, and patient assistance programs. 2020[Available from: https://www.drugs.com/price-guide/dexa methasone. Accessed: Accessed: 6 Nov 2020].

125. PharmaOffer.com. Producers, Manufacturers and Traders of Dexamethasone 2020 [Available from: https://api.pharmaoffer.com/api-excipient-supplier/ dexamethasone. Accessed: 6 Nov 2020].

126. Paranjpe I, Fuster V, Lala A, Russak AJ, Glicksberg BS, Levin MA, et al. Association of Treatment Dose Anticoagulation with in-Hospital Survival among Hospitalized Patients with COVID-19. J Am Coll Cardiol. 2020;76(1):122-4.

127. Tang N, Bai H, Chen X, Gong J, Li D, Sun Z. Anticoagulant treatment is associated with decreased mortality in severe coronavirus disease 2019 patients with coagulopathy. J Thromb Haemost. 2020;18(5):1094-9.

128. Kamel AM, Sobhy M, Magdy N, Sabry N, Farid S. Anticoagulation outcomes in hospitalized Covid-19 patients: a systematic review and meta-analysis of case-control and cohort studies. Rev Med Virol. 2020:e2180.

129. Lasky JA, Fuloria J, Morrison ME, Lanier R, Naderer O, Brundage T, et al. Design and rationale of a randomized, double-blind, placebo-controlled, phase 2/3 study evaluating Dociparstat in acute lung injury associated with severe COVID-19. Adv Ther. 2021;38(1):782-91.

130. Marietta M, Vandelli P, Mighali P, Vicini R, Coluccio V, D'Amico R. Randomised controlled trial comparing efficacy and safety of high versus low low-molecular weight heparin dosages in hospitalized patients with severe COVID-19 pneumonia and coagulopathy not requiring invasive mechanical ventilation (COVID-19 HD): a structured summary of a study protocol. Trials. 2020;21(1):574.

131. Dinnes J, Deeks JJ, Adriano A, Berhane S, Davenport C, Dittrich S, et al. Rapid, point-of-care antigen and molecular-based tests for diagnosis of SARS-CoV-2 infection. Cochrane Database Syst Rev. 2020;8:Cd013705.

132. Oladipo EK, Ajayi AF, Odeyemi AN, Akindiya OE, Adebayo ET, Oguntomi AS, et al. Laboratory diagnosis of COVID-19 in Africa: availability, challenges and implications. Drug Discov Ther. 2020;14(4):153-60.

133. Nkengasong J. Let Africa into the market for COVID-19 diagnostics. Nature. 2020;580(7805):565.

134. Rubin R. The challenges of expanding rapid tests to curb COVID-19. JAMA Network. 2020;324(18):1813-5.

135. Vandenberg O, Martiny D, Rochas O, van Belkum A, Kozlakidis Z. Considerations for diagnostic COVID-19 tests. Nat Rev Microbiol. 2020:1-13.

136. Africa Centres for Disease Control and Prevention. AU and Africa CDC launch Partnership to Accelerate COVID-19 Testing: Trace, Test and Track 2020 April 21 [Available from: https://africacdc.org/news-item/african-union-and-africacentres-for-disease-control-and-prevention-launch-partnership-to-acceleratecovid-19-testing-trace-test-and-track/. Accessed: 6 Nov 2020].

137. Musa HH, Musa TH, Musa IH, Musa IH, Ranciaro A, Campbell MC. Addressing Africa's pandemic puzzle: perspectives on COVID-19 infection and mortality in sub-Saharan Africa. Int J Infect Dis. 2021;102:483-8.

138. Bamgboye EL, Omiye JA, Afolaranmi OJ, Davids MR, Tannor EK, Wadee S, et al. COVID-19 pandemic: is Africa different? I Natl Med Assoc. 2020;500279684(20)30345-X.

139. Kirka D. AstraZeneca agrees to make COVID-19 vaccine for Europe. Medicaxpress. June 13 2020. Available at: https:/apnews.com/article/67f34 0b026a2b385af86838618db6cff\#: :text=LONDON\%20(AP)\%20\%E2\%80\% 94\%20Drugmaker\%20AstraZeneca,race\%20to\%20combat\%20the\%20virus. Accessed 18 Feb 2021. 
140. Joseph S. AstraZeneca taps emergent as U.S. partner for potential COVID-19 vaccine. Reuters. June 11 2020. Available at: https://www.reuters.com/article/ us-health-coronavirusastrazeneca-emerge/astrazeneca-taps-emergent-as-u-spartner-for-potential-covid-19-vaccineidUKKBN23I23U. Accesed 18 Feb 2021.

141. AstraZeneca. AstraZeneca takes next steps towards broad and equitable access to Oxford University's COVID-19 vaccine. 2020 [Available from: https://www.astrazeneca.com/media-centre/press-releases/2020/astra zeneca-takes-next-steps-towards-broad-and-equitable-access-to-oxforduniversitys-covid-19-vaccine.html. Accessed: 6 Nov 2020].

142. UNAIDS. The People's Vaccine 2020 [Available from: https://www.unaids. org/en/resources/presscentre/featurestories/2020/may/20200514_covid19-va ccine-open-letter. Accessed: 7 Nov 2020].

143. World Health Organization. International community rallies to support open research and science to fight COVID-19. 2020 [Available from: https://www. who.int/news/item/29-05-2020-international-community-rallies-to-supportopen-research-and-science-to-fight-covid-19. Accessed: 6 Nov 2020].

144. World Health Organization. Global vaccine action plan 2011-2020 2013 [Available from: http://www.who.int/immunization/global_vaccine_action_ plan/GVAP_doc_2011_2020/en/. Accessed: 6 Nov 2020].

145. Jadhav S, Gautam M, Gairola S. Role of vaccine manufacturers in developing countries towards global healthcare by providing quality vaccines at affordable prices. Clin Microbiol Infect. 2014;20(Suppl 5):37-44.

146. Africa Vaccine Manufacturing Initiative. Mission. 2019 [Available from: https://www.avmi-africa.org/about-us/mission/. Accessed: 7 Nov 2020].

147. Coalition for Epidemic Preparedness Innovations. Our Mission 2020 [Available from: https://cepi.net/about/whyweexist/. Accessed: 6 Nov 2020].

148. Conway M, Holt T, Sabow A, Sun I. Should sub-Saharan Africa make its own drugs? : McKinsey and Company; 2019 [Available from: https://www. mckinsey.com/industries/public-and-social-sector/our-insights/should-sub-sa haran-africa-make-its-own-drugs\#. Accessed: 6 Nov 2020].

149. Kurian O. Expanding pharmaceutical local production in Africa: an idea whose time has come? Health express; 2019.

150. This Day. Bank Begins Disbursement of Loans to Boost Nigerian Health Sector 2020 May 29. [Available from: https://www.thisdaylive.com/index. php/2020/05/29/bank-begins-disbursement-of-loans-to-boost-nigerian-hea Ith-sector/. Accessed: 7 Nov 2020].

151. World Health Organization. Measuring medicine prices, availability, affordability and price components 2008 [Available from: https://www. who.int/medicines/areas/access/medicines_prices08/en/. Accessed: 6 Nov 2020].

152. African Union Development Agency. African Medicines Regulatory Harmonisation 2019. [Available from: https://www.nepad.org/programme/a frican-medicines-regulatory-harmonisation-amrh. Accessed: 7 Nov 2020].

153. Sharma P. Indian Govt to set up dedicated parks for electronics and pharma companies 2020. [Available from: https://www.theweek.in/news/biz-tech/2 020/03/21/govt-to-set-up-dedicated-parks-for-electronics-and-pharmacompan.html. Accessed: 7 Nov 2020].

154. Moshood Y. Anukwu Explains how Pharma Parks will Help Pharma Manufacturing Sector: PharmaNews Nigeria; 2019 [Available from: https:// www.pharmanewsonline.com/anukwu-explains-how-pharma-parks-will-helppharma-manufacturing-sector/. Accessed: 6 Nov 2020.

155. Jayakumar P. Coronavirus: Pharma to get Rs 10,000 crore boost; 3 'Bulk Drug Parks' to be built 2020 [Available from: https://www.businesstoday.in/topstory/coronavirus-pharma-to-get-rs-10000-crore-boost-3-bulk-drug-parks-tobe-built/story/398901.html. Accessed: 7 Nov 2020].

156. African Development Bank Group. Ethiopia - Integrated Agro-Industrial Parks - Support Project (IAIPSP) - Appraisal Report 2019 [Available from: https:// www.afdb.org/en/documents/ethiopia-integrated-agro-industrial-parkssupport-project-iaipsp-appraisal-report. Accessed: 7 Nov 2020.

157. Ghosal A, Anna C. India, South Africa ask WTO to ease IP rules for COVID-19: Associated Press; 2020 [Available from: https://abcnews.go.com/Business/ wireStory/india-south-africa-wto-ease-ip-rules-covid-73402812. Accessed: 7 Nov 2020.

158. Coker M, Folayan MO, Michelow IC, Oladokun RE, Torbunde N, Sam-Agudu NA. Things must not fall apart: the ripple effects of the COVID-19 pandemic on children in sub-Saharan Africa. Pediatr Res. 2020. https://doi.org/10.1038/ s41390-020-01174-y.

159. Whitehead CL, Walker SP. Consider pregnancy in COVID-19 therapeutic drug and vaccine trials. Lancet. 2020;395(10237):e92.
160. Bill and Melinda Gates Foundation. Bill \& Melinda Gates Foundation, Wellcome, and Mastercard Launch Initiative to Speed Development and Access to Therapies for COVID-19 2020 March 10. [Available from: https:// www.gatesfoundation.org/Media-Center/Press-Releases/2020/03/COVID-19Therapeutics-Accelerator. Accessed: 7 Nov 2020].

161. Africa Centres for Disease Control and Prevention. Africa CDC, FIND partner to build capacity for COVID-19 rapid diagnostic tests in Africa. 2020 [Available from: https://africacdc.org/news-item/africa-cdc-find-partner-tobuild-capacity-for-covid-19-rapid-diagnostic-tests-in-africa. Accessed: 7 Nov 2020].

\section{Publisher's Note}

Springer Nature remains neutral with regard to jurisdictional claims in published maps and institutional affiliations.
Ready to submit your research? Choose BMC and benefit from:

- fast, convenient online submission

- thorough peer review by experienced researchers in your field

- rapid publication on acceptance

- support for research data, including large and complex data types

- gold Open Access which fosters wider collaboration and increased citations

- maximum visibility for your research: over $100 \mathrm{M}$ website views per year

At BMC, research is always in progress.

Learn more biomedcentral.com/submissions 